\title{
THE
}

\section{Design, Synthesis, Antiviral Activity, and Pre-Formulation Development of Poly-L-Arginine-Fatty Acyl Derivatives of Nucleoside Reverse Transcriptase Inhibitors}

\author{
Bhanu P. Pemmaraju \\ University of Rhode Island \\ Swapnil Malekar \\ University of Rhode Island \\ Hitesh K. Agarwal \\ University of Rhode Island
}

Eollow this and additional works at: https://digitalcommons.uri.edu/bps_facpubs
Rakesh Kiwari

The University of Rhode Island Faculty have made this article openly available.

Please let us know how Open Access to this research benefits you.

Phiversitypte-phoblicaland author manuscript of the final, published article.

Terms of Use

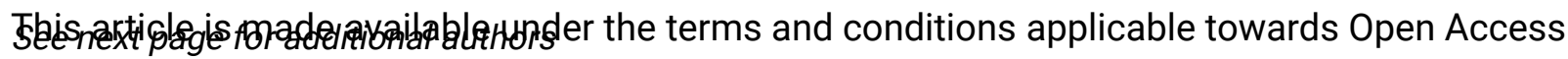
Policy Articles, as set forth in our Terms of Use.

\section{Citation/Publisher Attribution}

Bhanu P. Pemmaraju, Swapnil Malekar, Hitesh K. Agarwal, Rakesh K. Tiwari, Donghoon Oh, Gustavo F. Doncel, David R. Worthen \& Keykavous Parang (2015) Design, Synthesis, Antiviral Activity, and PreFormulation Development of Poly-L-Arginine-Fatty Acyl Derivatives of Nucleoside Reverse Transcriptase Inhibitors, Nucleosides, Nucleotides and Nucleic Acids, 34:1, 1-15. DOI: 10.1080/15257770.2014.945649 Available at: http://dx.doi.org/10.1080/15257770.2014.945649

This Article is brought to you for free and open access by the Biomedical and Pharmaceutical Sciences at DigitalCommons@URI. It has been accepted for inclusion in Biomedical and Pharmaceutical Sciences Faculty Publications by an authorized administrator of DigitalCommons@URI. For more information, please contact digitalcommons-group@uri.edu. 


\section{Authors}

Bhanu P. Pemmaraju, Swapnil Malekar, Hitesh K. Agarwal, Rakesh K. Tiwari, Donghoon Oh, Gustavo F. Doncel, David R. Worthen, and Keykavous Parang 


\section{Design, Synthesis, Antiviral Activity, and Pre- Formulation Development of Poly-L-Arginine- Fatty Acyl Derivatives of Nucleoside Reverse Transcriptase Inhibitors}

Bhanu P. Pemmaraju, Swapnil Malekar, Hitesh K. Agarwal, Rakesh K. Tiwari, Donghoon Oh, Gustavo F. Doncel, David R. Worthen \& Keykavous Parang

To cite this article: Bhanu P. Pemmaraju, Swapnil Malekar, Hitesh K. Agarwal, Rakesh K.

Tiwari, Donghoon Oh, Gustavo F. Doncel, David R. Worthen \& Keykavous Parang (2015) Design, Synthesis, Antiviral Activity, and Pre-Formulation Development of Poly-L-Arginine-Fatty Acyl Derivatives of Nucleoside Reverse Transcriptase Inhibitors, Nucleosides, Nucleotides and Nucleic Acids, 34:1, 1-15, DOI: 10.1080/15257770.2014.945649

To link to this article: https://doi.org/10.1080/15257770.2014.945649

Published online: 16 Dec 2014.

Submit your article to this journal $₫$

Џlll Article views: 202

View Crossmark data ¿

Citing articles: 3 View citing articles $\square$ 


\title{
DESIGN, SYNTHESIS, ANTIVIRAL ACTIVITY, AND PRE-FORMULATION DEVELOPMENT OF POLY-L- ARGININE-FATTY ACYL DERIVATIVES OF NUCLEOSIDE REVERSE TRANSCRIPTASE INHIBITORS
}

\author{
Bhanu P. Pemmaraju, ${ }^{1}$ Swapnil Malekar, ${ }^{1}$ Hitesh K. Agarwal, ${ }^{1}$ \\ Rakesh K. Tiwari, ${ }^{1,2}$ Donghoon Oh, ${ }^{1}$ Gustavo F. Doncel, ${ }^{4}$ David R. Worthen, ${ }^{1}$ \\ and Keykavous Parang 1,2,3 \\ ${ }^{1}$ Department of Biomedical and Pharmaceutical Sciences, College of Pharmacy, University of \\ Rhode Island, Kingston, RI, United States \\ ${ }^{2}$ Chapman University, School of Pharmacy, Irvine, CA, United States \\ ${ }^{3}$ Chao Family Comprehensice Cancer Center, School of Medicine, University of California, \\ Irvine, Shanbrom Hall, Orange, CA, United States \\ ${ }^{4}$ CONRAD, Department of Obstetrics and Gynecology, Eastern Virginia Medical School, \\ Norfolk, VA, United States
}

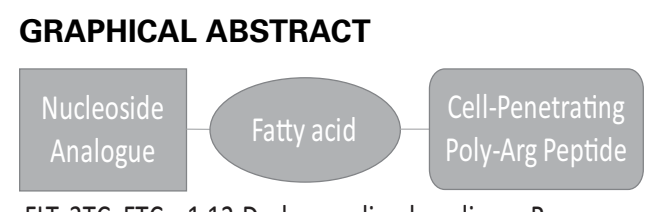

\footnotetext{
FLT, 3TC, FTC 1,12-Dodecanedicarboxylic $\quad R_{7}$ acid
}

$\square \quad$ The objective of this work was to design conjugates of anti-HIV nucleosides conjugated with fatty acids and cell-penetrating poly-L-arginine (polyArg) peptides. Three conjugates of polyArg cellpenetrating peptides with fatty acyl derivatives of alovudine (FLT), lamivudine (3TC), and emtricitabine (FTC) were synthesized. In general, the compounds exhibited anti-HIV activity against X4 and $\mathrm{R} 5$ cell-free virus with $\mathrm{EC}_{50}$ values of 1.5-16.6 $\mu \mathrm{M}$. FLT-CO- $\left(\mathrm{CH}_{2}\right)_{12}-\mathrm{CO}-(\mathrm{Arg})_{7}$ exhibited $E C_{50}$ values of $2.9 \mu \mathrm{M}$ and $3.1 \mu \mathrm{M}$ against $X 4$ and $R 5$ cell-free virus, respectively. The FLT conjugate was selected for further preformulation studies by determination of solution state degradation and lipid solubility. The compound was found to be stable in neutral and oxidative conditions and moderately stable in heated conditions.

Received 16 June 2014; accepted 13 July 2014.

The views expressed by the authors do not necessarily reflect the views of USAID or CONRAD.

Address correspondence to K. Parang: Chao Family Comprehensice Cancer Center, School of Medicine, University of California, Irvine, Shanbrom Hall, 101 The City Drive, Orange, CA 92868. E-mail: parang@chapman.edu 
Keywords anti-HIV agents; fatty acids; lipophilicity; nucleosides; polyarginine; reverse transcriptase

\section{INTRODUCTION}

According to UNAIDS estimation, 35.3 million people are living with Acquired Immunodeficiency Syndrome (AIDS) as of 2013. High Activity Antiretroviral Therapy (HAART) involves the use of a minimum of three antiretroviral drugs including protease inhibitors, non-nucleoside reverse transcriptase inhibitors, and nucleoside reverse transcriptase inhibitors. HAART has increased the lifespan of HIV-infected patients and has converted this terminal illness into a chronic and manageable disease. ${ }^{[1]}$ Although the FDA-approved anti-HIV nucleosides zidovudine (AZT), lamivudine (3TC), and emtricitabine (FTC) have reduced the mortality rate in patients, their use is still complicated because of toxicity, chronic dosage, development of resistant virus, and incomplete elimination of the viral reservoirs. Moreover, these anti-HIV nucleosides have limited cellular uptake due to their hydrophilic nature. Upon intracellular uptake, they need to undergo three phosphorylation steps in order to become active nucleoside triphosphate analogues. ${ }^{[1]}$ Thus, novel drug-delivery systems are urgently needed in order to generate nucleoside conjugates with better anti-HIV profile, such as higher cellular uptake and anti-HIV activity.

The primary objective of this work was to design conjugates of antiHIV nucleosides conjugated with fatty acids and cell-penetrating polyArg peptides. Herein, we designed polyArg-fatty acyl derivatives of anti-HIV nucleosides with the expectation to overcome their limited cellular uptake. The objective was to design multifunctional anti-HIV drug conjugates where:

1. Nucleosides act as reverse transcriptase inhibitors (NRTIs);

2. Long-chain fatty acyl component acts as an $N$-myristoyl transferase (NMT) inhibitor and also improves cellular uptake; and

3. The poly- $L$-arginine component plays a crucial role as a cell-penetrating peptide.

\section{Long-Chain Carboxylic Acids as NMT Inhibitors}

Long-chain carboxylic acids are known to inhibit NMT, which is responsible for the myristoylation of various HIV proteins, such as P17 capsid protein, Pr55 $5^{\mathrm{gag}}$, Pr160 ${ }^{\mathrm{gag}-\mathrm{pol}}$, and $\mathrm{p} 27^{\mathrm{nef}}$ in the virus-infected host cells. ${ }^{[2]}$ Myristoylation of viral proteins allows the viral protein components to become more hydrophobic. ${ }^{[3]}$ Certain heteroatom-containing myristic acid analogues, such as 12-thioethyldodecanoic acid, 4-oxatetradecanoic acid, and 2-methoxydodecanoic acid derivatives, inhibit HIV-1 replication in acutely infected T-lymphocytes. ${ }^{[4,5]}$ 12-Thioethyldodecanoic acid was found 
to be moderately active against HIV-infected T4 lymphocytes with an $\mathrm{EC}_{50}$ value of $9.4 \mu \mathrm{M} .^{[6]}$

Various 5'-O-fatty acyl derivatives of nucleoside reverse transcriptase inhibitors ( $3^{\prime}$-azido-3'-deoxythymidine (zidovudine, AZT), 3'-fluoro-3'deoxythymidine (alovudine, FLT), (-)-2', $3^{\prime}$-dideoxy-3'-thiacytidine (lamivudine, 3TC), 5-fluoro-(-)-2', 3'-dideoxy-3'-thiacytidine (emtricitabine, FTC), $2^{\prime}, 3^{\prime}$-didehydro-2', $3^{\prime}$-dideoxythymidine (stavudine, d4T) were found to have enhanced anti-HIV activity profiles as compared with their parent nucleosides against X4, R5 strains, and cell-associated virus, presumably due to increased cellular uptake caused by their high lipophilic profile. ${ }^{[6-14]}$ These ester conjugates and others reported by other researchers ${ }^{[15,16]}$ were expected to act as bifunctional agents through intracellular hydrolysis by esterases to release nucleoside reverse transcriptase inhibitors and fatty acids.

\section{Poly-L-Arginine as a Cell-Penetrating Peptide}

An important subclass of these molecular transporters are CPPs, which contain guanidinium-rich transporters (GRTs). The positively charged guanidinium groups on the arginine side chains are responsible for its penetrating ability through interaction with the phospholipid bilayer. The development of these polyarginine transporter molecules was inspired by the lead HIV-1 transcription transactivator protein (Tat) made up of repeated arginine and lysine residues. ${ }^{[14]}$ This transporter is highly polar, readily soluble in water, and, unlike other polar drugs, travels across the lipid bilayer membrane. ${ }^{[17]}$ Studies have shown that peptides with 6-20 arginine residues pass through the membrane, showing rapid uptake across the membrane and into the nucleus without any signs of acute toxicity. ${ }^{[17]}$ Molecular transporters, when attached to poorly bioavailable drugs, could enable them to pass through the biological membrane as shown previously. ${ }^{[18]}$

Herein, we report the design, synthesis, and biological activities of three poly-L-arginine-linked (poly-Arg) 1,12-dodecanedicarboxylate derivatives of anti-HIV nucleosides (FLT, 3TC, and FTC; Figure 1) and their application

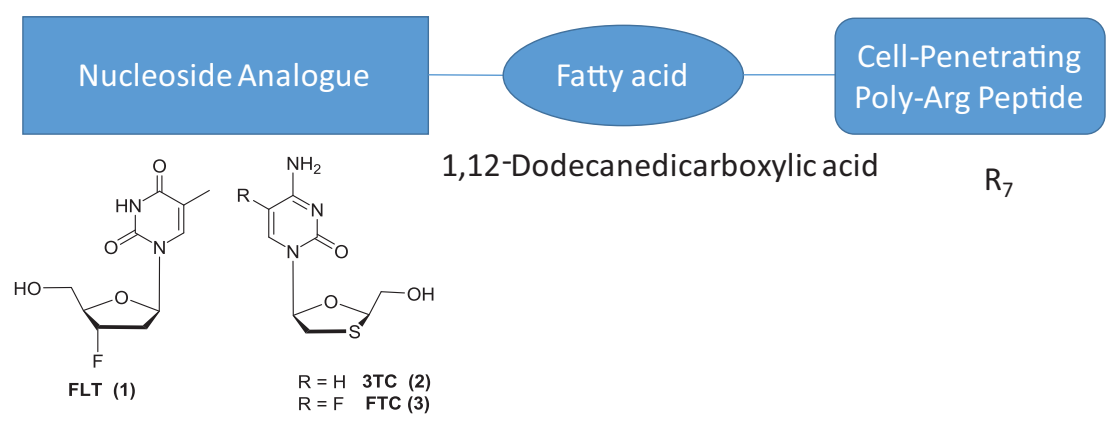

FIGURE 1 Poly- $L$-arginine-linked fatty acylated nucleosides. (Color figure available online). 
as multifunctional anti-HIV agents. It was expected that the conjugation of nucleosides to the poly- $L$-arginine-fatty acyl residue could result in the development of anti-HIV agents with enhanced efficacy, and/or higher uptake into infected cells.

\section{RESULTS AND DISCUSSION}

FLT (1), N4-amino-protected 3TC (8), N4-amino-protected FTC (9), and 1,12-dodecandicarboxylate-polyarginine resin were used as the building blocks. N4-DMTr-3TC (8) and N4-DMTr-FTC (9) were synthesized according to a previously reported procedure. ${ }^{[12]}$ First, tert-butyldimethylsilyl chloride (TBDMS-Cl) was reacted with 3TC (2) or FTC (3) in the presence of imidazole to afford 5'-O-TBDMS-3TC (4) or 5'-O-TBDMS-FTC (5). Next, the N4-amino group of $\mathbf{4}$ and $\mathbf{5}$ was protected with 4,4'-dimethoxytrityl (DMTr) protecting group, by reaction with DMTr-Cl in the presence of pyridine to yield 6 and 7, respectively. Finally, TBDMS was removed by using tetrabutylammonium fluoride (TBAF) to yield N4-DMTr-3TC (8) and N4-DMTr-FTC (9) (Scheme 1).

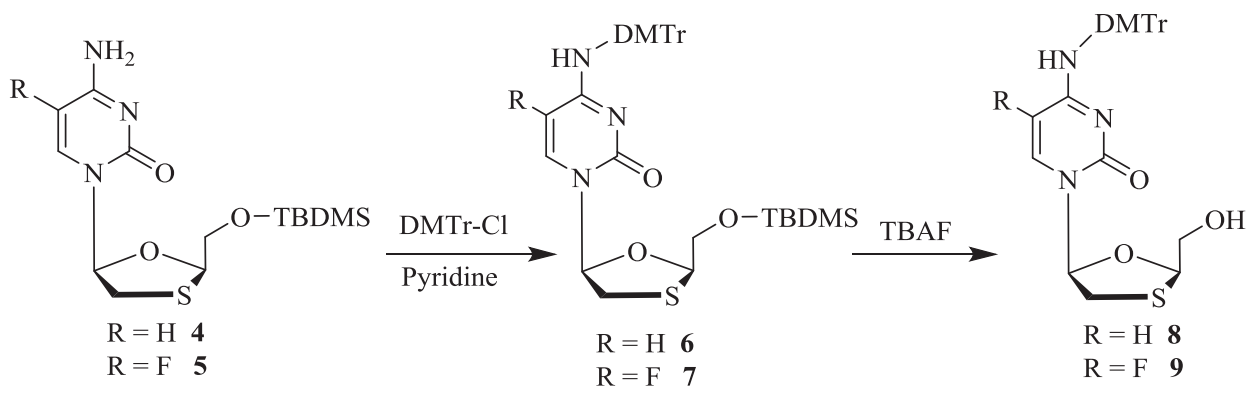

SCHEME 1 Synthesis of N4-DMTr protected of FTC and 3TC nucleosides. ${ }^{[12]}$

Second, the polyarginine peptide $\left(\mathrm{R}_{7}\right)$ was manually synthesized by agitation of resin using nitrogen gas with a solid-phase Fmoc/ $t \mathrm{Bu}$ strategy. The preloaded Fmoc- $L$-arginine(Pbf)-Wang resin (10) was swelled in DMF, and this was followed by deprotection of Fmoc group by using $20 \%$ piperidine in DMF.

The resin was washed with DMF and coupled with Fmoc-Arg $(\mathrm{Pbf})$ $\mathrm{OH}$ in the presence of coupling reagents 1,1,3,3-tetramethyluronium hexafluorophosphate (HBTU) and $N, N$-diisopropylethylamine (DIPEA) as a base, respectively, in DMF at room temperature under nitrogen. The deprotection and coupling cycles were repeated 5 more times, followed by the final $N$-terminal Fmoc de-protection using $20 \%$ piperidine in DMF to yield $\mathrm{NH}_{2}$-polyarginine-Wang resin 11. A small amount of resin cleavage confirmed the assembly of polyarginine peptide on Wang resin. 1,12Dodecanedicarboxylic acid was coupled to $\mathrm{NH}_{2}$-polyarginine Wang resin 11 
to yield 1,12-dodecanedicarboxylate-polyarginine resin 12 in the presence of a combination of coupling reagents (HBTU, HOAt, and DIC; Scheme 2).

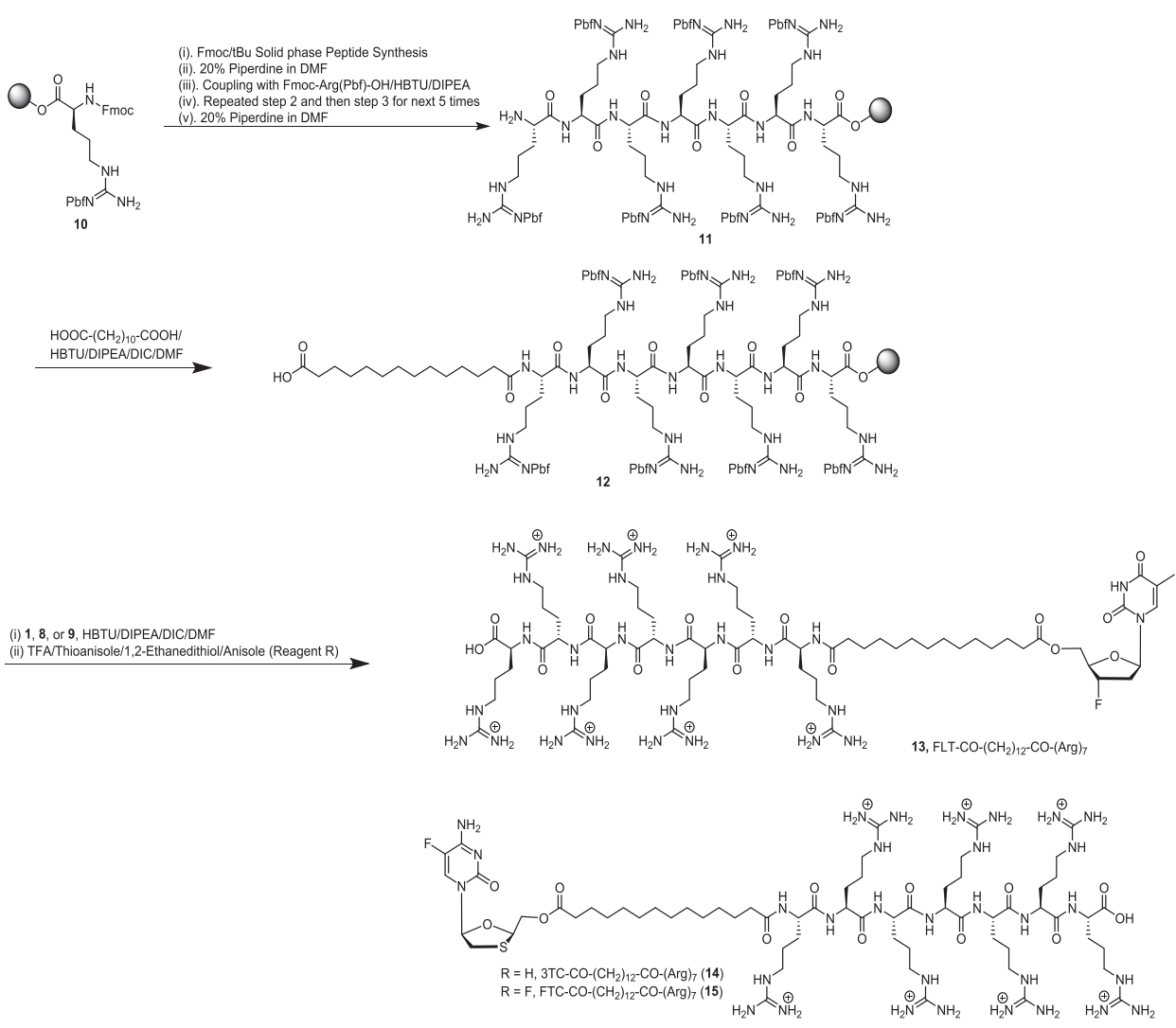

SCHEME 2 Synthesis of hepta- $L$-arginyl-1,12-dodecanedicarboxylate-nucleoside conjugates 13-15.

Peptidyl polyarginine dodecandicarboxylate resin 12 was conjugated with the nucleoside analogues $(\mathbf{1}, \mathbf{8}$, or $\mathbf{9})$ in the presence of HBTU, HOAt DIPEA, and DIC in anhydrous DMF (Scheme 2). The resin was cleaved along with the deprotection of $\mathrm{Pbf}$ and $\mathrm{DMTr}$ protective groups from the side chain of arginine and the corresponding nucleosides, respectively, using reagent $\mathrm{R}$ for 4 hours at room temperature. The conjugates were purified by preparative reverse-phase HPLC. The purity of final products $(>95 \%)$ was confirmed by analytical HPLC. The chemical structures of compounds were determined by a SELDI-TOF mass spectrometer on a Ciphergen protein chip instrument using $\alpha$-cyano-4-hydroxycinnamic as a matrix and by ${ }^{1} \mathrm{H}$ and ${ }^{13} \mathrm{C}$ NMR.

The anti-HIV activity of the compounds was evaluated according to a previously reported procedure. ${ }^{[11,19-21]}$ Table 1 shows the anti-HIV activities of the conjugates compared to their parent analogues. No cellular cytotoxicity 
TABLE 1 Anti-HIV activity of dicarboxylic acid ester conjugates of nucleoside conjugates (1-7)

\begin{tabular}{|c|c|c|c|c|c|}
\hline \multirow[b]{2}{*}{ Compound } & \multirow[b]{2}{*}{ Chemical Name } & \multirow{2}{*}{$\begin{array}{c}\text { Cytotoxicity } \\
\text { CTS }^{\mathrm{a}} \mathbf{E C}_{\mathbf{5 0}} \\
\mathbf{b}_{(}(\mu \mathbf{M})\end{array}$} & \multicolumn{2}{|c|}{ Cell-Free Virus } & \multirow{2}{*}{$\begin{array}{c}\text { Cell-Associated } \\
\text { Virus } \\
\mathrm{CTC}^{\mathrm{e}} \mathrm{EC}_{50} \\
(\mu \mathrm{M})\end{array}$} \\
\hline & & & $\begin{array}{c}\mathrm{X}^{\mathrm{c}} \mathrm{EC}_{50} \\
(\mu \mathrm{M})\end{array}$ & $\begin{array}{l}\mathrm{R}^{\mathrm{d}} \mathrm{EC}_{50} \\
\quad(\mu \mathrm{M})\end{array}$ & \\
\hline FLT (1) & 3'-Fluoro-2', 3'-deoxythymidine & $>100$ & 0.2 & 0.1 & $>100$ \\
\hline $3 \mathrm{TC}(2)$ & $(-)-2^{\prime}, 3^{\prime}$-Dideoxy-3'-thiacytidine & $>100$ & 7.5 & 2.6 & 18.4 \\
\hline FTC (3) & (-) $2^{\prime}, 3^{\prime}$-Dideoxy-5-fluoro-3'-thiacytidine & $>100$ & 0.48 & 0.18 & 21.9 \\
\hline 13 & FLT-CO- $\left(\mathrm{CH}_{2}\right)_{12}-\mathrm{CO}-\mathrm{R}_{7}$ & $>30$ & 2.9 & 3.1 & $>30$ \\
\hline 14 & $3 \mathrm{TC}-\mathrm{CO}-\left(\mathrm{CH}_{2}\right)_{12}-\mathrm{CO}-\mathrm{R}_{7}$ & $>30$ & 8.7 & 16.6 & $>30$ \\
\hline 15 & FTC-CO- $\left(\mathrm{CH}_{2}\right)_{12}-\mathrm{CO}-\mathrm{R}_{7}$ & $>30$ & 3.0 & 1.5 & $>30$ \\
\hline
\end{tabular}

${ }^{\mathrm{a} C y t o t o x i c i t y ~ a s s a y ~(M T S) ; ~}{ }^{\mathrm{b}} 50 \%$ Effective concentration; ${ }^{\mathrm{c}}$ Single-round infection assay (lymphocytotropic strain, X4); ${ }^{\mathrm{d} S i n g l e-r o u n d ~ i n f e c t i o n ~ a s s a y ~(m o n o c y t o t r o p i c ~ s t r a i n, ~ R 5) ; ~}{ }^{\mathrm{e}}$ Cell-associated transmission assay (X4).

was observed up to the highest tested concentration for the conjugates $\left(\mathrm{EC}_{50}\right.$ $>30 \mu \mathrm{M})$. The conjugates showed no significant anti-HIV activity against cell-associated virus $\left(\mathrm{EC}_{50}>30 \mu \mathrm{M}\right)$. All conjugates exhibited less anti-HIV activity when compared with the parent nucleoside analogues against cellfree virus. FLT conjugate $13\left(\mathrm{EC}_{50}=2.9-3.1 \mu \mathrm{M}\right)$ showed lesser potency than its parent nucleoside $\left(\mathrm{EC}_{50}=0.1-0.2 \mu \mathrm{M}\right)$ against $\mathrm{X} 4$ and $\mathrm{R} 5$ cell-free virus. FTC conjugate $15\left(\mathrm{EC}_{50}=1.5-3.0 \mu \mathrm{M}\right)$ showed less anti-HIV-1 activity when compared to that of FTC $\left(\mathrm{EC}_{50}=0.18-0.48 \mu \mathrm{M}\right)$ against $\mathrm{X} 4$ and $\mathrm{R} 5$ cell-free virus. The 3TC conjugate $\mathbf{1 4}$ not only showed approximately 2-fold higher inhibition against the $\mathrm{X} 4$ virus $\left(\mathrm{EC}_{50}=8.7 \mu \mathrm{M}\right)$ than against the $\mathrm{R} 5$ virus strain $\left(\mathrm{EC}_{50}=16.6 \mu \mathrm{M}\right)$, but also exhibited less potency than that of 3TC $\left(\mathrm{EC}_{50}=2.6-7.5 \mu \mathrm{M}\right)$. The conjugates were less potent than their parent structures possibly due to the limited uptake. Different strains of HIV are known to have different gp120 V3 loops. Both the X4 and R5 strains of HIV possess a high positive charge density on their V3 loop, ${ }^{[22,23]}$ suggesting that the presence of positive charge on the conjugates could block the interaction with gp120. Thus, these conjugates exhibited lesser anti-HIV activity when compared with their parent analogues because of the limited cellular uptake.

To better understand the physicochemical properties of these compounds in designing more optimized compounds, we further explored the stability and lipid solubility of these compounds. As the FLT-conjugate contains several potentially labile bonds, forced degradation of an aqueous solution of 13 at elevated temperature, in acid, base, and under oxidizing conditions, were conducted. Compound 13 was selected for further evaluation in solution-state degradation studies and determination of lipid solubility (partition coefficient) Thus, it was necessary to determine the relative stability of these compounds under different conditions. Furthermore, these 

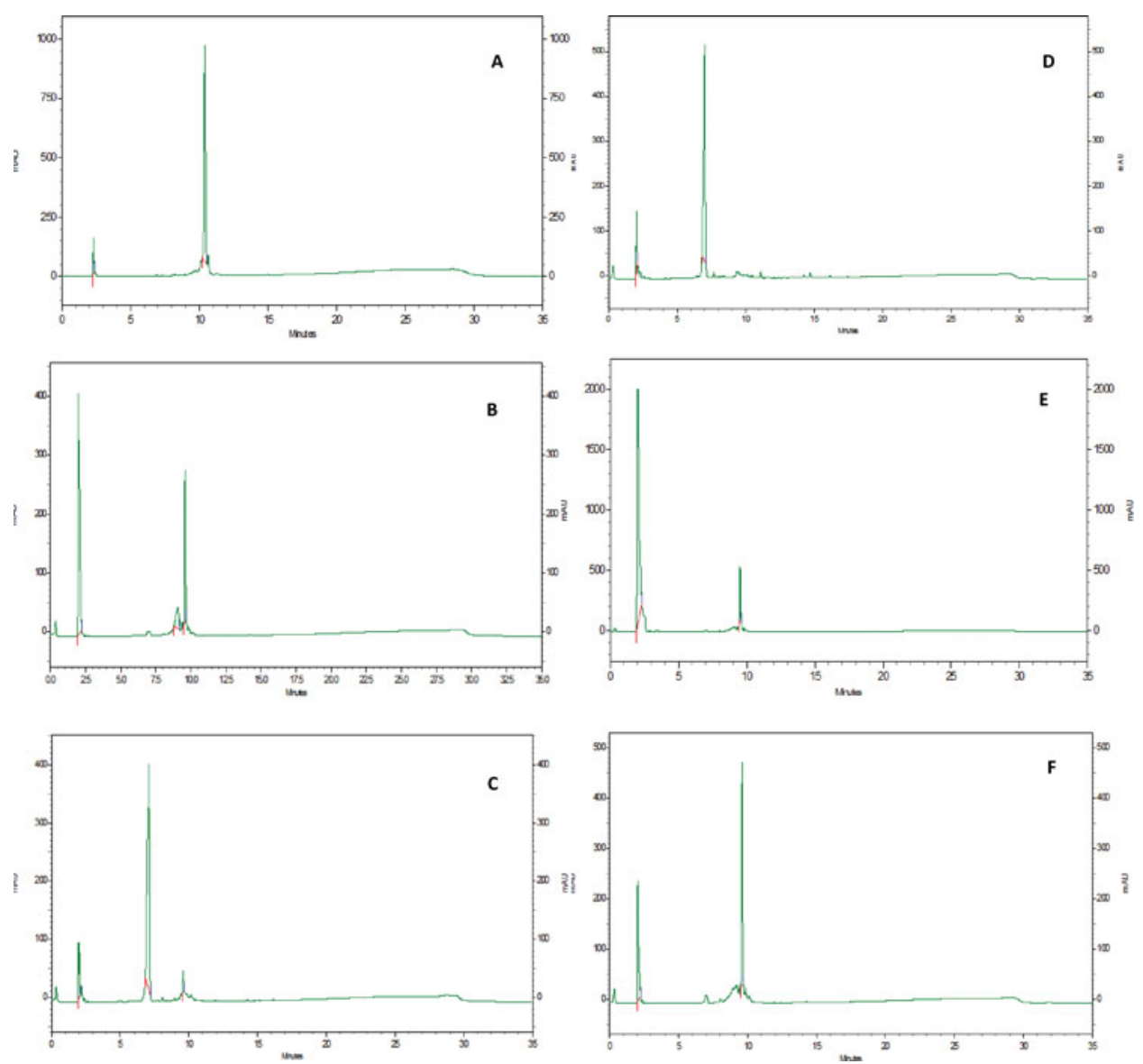

FIGURE 2 Degradation studies of FLT conjugate 13. A: Standard 13, Retention time 9.7 minutes; B: Heat: $1 \mathrm{~mL}$ stock $+1 \mathrm{~mL}$ methanol at $40^{\circ} \mathrm{C}$; $\mathbf{C}$ : Acid: $1 \mathrm{~mL}$ stock $+1 \mathrm{~mL} 1 \mathrm{~N} \mathrm{HCl}$ at $40^{\circ} \mathrm{C}$; D: Base: $1 \mathrm{~mL}$ stock $+1 \mathrm{~mL} 1 \mathrm{~N} \mathrm{NaOH}$ at $40^{\circ} \mathrm{C}$; $\mathbf{E}$ : Oxidation: $1 \mathrm{~mL}$ stock $+1 \mathrm{~mL} \mathrm{H}_{2} \mathrm{O}_{2}$ at $40^{\circ} \mathrm{C}$; $\mathbf{F}$ : Water: $1 \mathrm{~mL}$ stock $+1 \mathrm{~mL} \mathrm{H}_{2} \mathrm{O}$ at $40^{\circ} \mathrm{C}$. (Color figure available online).

conjugates were designed to be used in areas where shipping and storage conditions are not ideal in terms of temperature and humidity.

At heated (panel B) conditions, significant degradation of the compound 13 was observed resulting in a second HPLC peak at 9 minutes. Under both acidic and alkaline conditions, the compound degraded to a great extent resulting in a different peak at 7 minutes (panels C and D). Minimal degradation of the drug was noted at neutral (panel E) and oxidative $\left(\mathrm{H}_{2} \mathrm{O}_{2}\right.$; panel F) conditions (Figure 2). Thus, the FLT conjugate was relatively stable in neutral and oxidative conditions, but less stable in heated, acidic, and alkaline conditions.

The Log $\mathrm{P}$ of the compound was determined by distributing the compound between an equal volume of $n$-octanol (organic) and $\mathrm{pH} 4$ acetate 
buffer (aqueous) with stirring at room temperature for 2 days, followed by HPLC studies. The Log P of the compound was found to be -0.34 , indicating that the compound is hydrophilic, most likely due to the presence of several guanidinium moieties from hepta- $L$-arginine. FLT has a Log P value of -0.52 . These data suggest that the compound is still very hydrophilic despite the presence of the long 1,12-dodecane dicarboxylic acid linker.

Various gel formulations of the compound were manufactured using non-ionic (HPC-SL) and anionic (Carbopol) polymers, with or without the inclusion of the thermo-reversible gelling (Pluronic F-127) polymer. The derivative was used for dissolution studies using four different gels, with or without the thermogelling polymer. The HPC-SL formulation consisted of $2.25 \% \mathrm{w} / \mathrm{v}$ in water whereas Carbopol consisted of $0.2 \% \mathrm{w} / \mathrm{v}$. For the thermogelling formulations, the HPC-SL and Carbopol gels were mixed with $20 \% \mathrm{w} / \mathrm{v}$ solution of Pluronic F-127(3:1 v/v ratio) in water. The formulations were then sealed in dialysis tubes, and the rate and extent of compound dissolution were determined in simulated vaginal fluid at $37^{\circ} \mathrm{C}$. There was no observed drug release that could be identified by UV spectrophotometry at 220 and $256 \mathrm{~nm}$, suggesting that the compound was unstable in these formulations.

\section{CONCLUSIONS}

In conclusion, three poly-L-arginyl-1,12-dodecanedicarboxylate nucleoside conjugates of FLT, 3TC, and FTC were designed and synthesized using solid-phase chemistry. The structures of the compounds were confirmed by NMR and mass spectroscopy. The compounds were evaluated for their anti-HIV activity against cell-free and cell-associated virus. FLT conjugate 13 showed $\mathrm{EC}_{50}$ values of 2.9-3.1 $\mu \mathrm{M}$ against $\mathrm{X} 4$ and $\mathrm{R} 5$ virus. The compound was relatively stable in neutral and oxidative conditions, and unstable in heated, acidic, and alkaline conditions. The FLT conjugate was hydrophilic, as the $\log \mathrm{P}$ was found to be -0.34 . The derivative was evaluated in dissolution studies using four different hydrogels gels with and without a thermogelling polymer. Gel formulations of the compound were manufactured using non-ionic (HPC-SL) and anionic (Carbopol) polymers with or without the inclusion of a thermo-reversible gelling (Pluronic F-127) polymer. The compound was unstable or did not undergo release from the tested hydrogel formulations. These data indicate that the presence of positively charged CPP could impede the interactions between positively charged V3 loop in gp120 and the conjugates. Further optimization of conjugated CPP-fatty acid-nucleoside conjugates is required to generate compounds with improved anti-HIV activity and optimized stability and formulation performance. 


\section{EXPERIMENTAL}

\section{Materials and Methods}

\section{Materials}

Nucleosides (1-3) were purchased from Euro Asia Trans Continental (Bombay, India) for the nucleoside ester conjugate synthesis. [2(1H-benzotriazol-1-yl)-1,1,3,3-tetramethyluronium-hexafluorophosphate] (HBTU), N,N-diisopropylethylamine (DIPEA), and 1,12-dodecanedicarboxylic acid were bought from Sigma Aldrich Chemical Co. Solvents and all other reagents were purchased from Fisher Scientific. The products were purified using a Phenomenex-Gemini C18 column $(10 \mu \mathrm{m}, 250 \times 21.2 \mathrm{~mm})$ with Hitachi HPLC system using a gradient system at a constant flow rate of $10 \mathrm{~mL} /$ minute (Table 2 ). The purity of the final products was confirmed by using a Hitachi analytical HPLC system on a C18 column using a gradient system (water:acetonitrile $30: 70 \mathrm{v} / \mathrm{v}$ ) at a constant flow rate of $1 \mathrm{~mL} /$ minute with UV detection at 220 and $265 \mathrm{~nm}$. The chemical structures of the final products were determined by NMR spectrometry $\left({ }^{1} \mathrm{H}\right.$ NMR and ${ }^{13} \mathrm{C}$ NMR) on a Bruker NMR spectrometer (400 MHz) and confirmed by a SELDI-TOF mass spectrometer on a Ciphergen protein chip instrument using $\alpha$-cyano-4-hydroxycinnamic acid as a matrix.

\section{Chemistry}

Synthesis of Polyarginine (11). The peptide synthesis was carried out in Bio-Rad polypropylene columns by shaking and mixing using a Glass Col small tube rotator or on a PS3 automated peptide synthesizer (Rainin Instrument Co., Inc.) at room temperature unless otherwise stated. Fmoc$\operatorname{Arg}(\mathrm{Pbf})$-Wang resin (10, $1.1 \mathrm{mmole}, 2.97 \mathrm{~g}, 0.37 \mathrm{mmole} / \mathrm{g})$ was placed in a manual peptide synthesis container $(250 \mathrm{~mL})$ equipped with a three-way stopper. Resin was swelled in $N, N$-dimethylformamide (DMF, $150 \mathrm{~mL}$ ) with constant $\mathrm{N}_{2}$ bubbling for 30 minutes (2 times). The Fmoc group was removed

TABLE 2 HPLC method used for purification of the final compounds

\begin{tabular}{lccc}
\hline Time (minute) & $\begin{array}{c}\text { Water Concentration } \\
\text { A (\%) }\end{array}$ & $\begin{array}{c}\text { Acetonitrile Concentration } \\
\text { B (\%) }\end{array}$ & $\begin{array}{c}\text { Flow Rate } \\
(\mathrm{mL} / \mathrm{minute})\end{array}$ \\
\hline 0.00 & 100.0 & 0.0 & 1.0 \\
1.00 & 100.0 & 0.0 & 10.0 \\
5.0 & 90.0 & 10.0 & 10.0 \\
25.0 & 70.0 & 30.0 & 10.0 \\
35.0 & 60.0 & 40.0 & 10.0 \\
60.0 & 0.0 & 100.0 & 10.0 \\
65.0 & 0.0 & 100.0 & 10.0 \\
70.0 & 100.0 & 0.0 & 1.0 \\
\hline
\end{tabular}


from the resin in the presence of piperidine $(20 \% \mathrm{v} / \mathrm{v}$ in DMF, $2 \times 50 \mathrm{~mL})$ for 15 minutes. The resin was washed with DMF $(5 \times 50 \mathrm{~mL})$. Fmoc-Arg $(\mathrm{Pbf})$ $\mathrm{OH}$ (3 equiv, $3.3 \mathrm{mmol}, 2.14 \mathrm{~g}$ ) and HBTU (3 equiv, $1.25 \mathrm{~g}, 3.3 \mathrm{mmol}$ ) were added to the reaction vessel, followed by the addition of DMF (25 mL) and DIPEA (6 equiv, $6.6 \mathrm{mmol}, 1.15 \mathrm{~mL}$ ) (Scheme 2) and bubbled with $\mathrm{N}_{2}$ for 2.5 hours. The resin was washed with DMF $(5 \times 25 \mathrm{~mL})$ to remove unreacted starting materials, impurity, and reagents. The deprotection and coupling cycles were repeated 5 more times to add a total of seven arginine residues on the resin. $N$-Terminal Fmoc was deprotected using piperidine $(20 \% \mathrm{v} / \mathrm{v}$ in DMF) to afford resin 11. Resin 11 was washed with DMF $(5 \times 100 \mathrm{~mL})$. The structure of $\mathbf{1 1}$ was confirmed by cleaving a small amount of the resin in the presence of reagent $\mathrm{R}$ (TFA/thioanisole/1,2-ethanedithiol/anisole, 90:5:3:2 v/v/v/v, $2 \mathrm{~mL}$ ) for 4 hours. The crude peptide was precipitated in the presence of cold diethyl ether $\left(\mathrm{Et}_{2} \mathrm{O}, 150 \mathrm{~mL}\right)$, and separated and washed by centrifugation $(3 \times 15 \mathrm{~mL})$ at $4000 \mathrm{rpm}$ for 5 minutes. The crude peptide was dissolved in water $(0.1 \%$, TFA). The molecular weight of poly-L-arginine $\left(\mathrm{R}_{7}\right)$ was confirmed by a SELDI-TOF mass spectrometer on a Ciphergen protein chip instrument. MS (SELDI-TOF) (m/z): $\mathrm{C}_{42} \mathrm{H}_{86} \mathrm{~N}_{28} \mathrm{O}_{8}$, calcd, 1111.3; found, $1111.1[\mathrm{M}]^{+}$.

Synthesis of Polyarginine 1,12-Dodecanedicarboxylate (12). 1,2Dodecanedicarboxylic acid (1.43 g, $5.5 \mathrm{mmol})$, HBTU (2.09 g, $5.5 \mathrm{mmol})$, and 1-hydroxy-7-azabenzotriazole (HOAt, $0.74 \mathrm{~g}, 5.5 \mathrm{mmol}$ ) were added to the reaction vessel containing polyarginine resin 11 in anhydrous DMF $(200 \mathrm{~mL})$, followed by the addition of DIPEA $(8.1 \mathrm{mmol}, 1.42 \mathrm{~mL})$ and $N, N^{\prime}-$ diisopropylcarbodiimide (DIC, $9.0 \mathrm{mmol}, 1.4 \mathrm{~mL}$; Scheme 2). The peptidtyl resin was bubbled with $\mathrm{N}_{2}$ for 7 hours and then washed with DMF ( $5 \times$ $100 \mathrm{~mL})$. Resin 12 was finally washed with DMF $(5 \times 150 \mathrm{~mL})$. A small amount of the resin was cleaved using reagent $\mathrm{R}$ (TFA/thioanisole/1,2ethanedithiol/anisole, 90:5:3:2 v/v/v/v, $2 \mathrm{~mL}$ ) for 4 hours, precipitated with cold diethyl ether $(200 \mathrm{~mL})$, and finally centrifuged at $4000 \mathrm{rpm}$ for 5 minutes. The residue was dissolved in water, and the formation of product 12 was confirmed with a SELDI-TOF mass spectrometer. MS (SELDI-TOF) $(\mathrm{m} / \mathrm{z}): \mathrm{C}_{56} \mathrm{H}_{110} \mathrm{~N}_{28} \mathrm{O}_{11}$, calcd, 1351.7; found, $1352.0[\mathrm{M}+\mathrm{H}]^{+}$.

General Procedure for the Synthesis of Polyarginine-1,12Dodecanedicarboxylate Acylated Nucleoside Analogues (13-15). N4-4,4'Dimethoxytrityl (DMTr)-3TC (8) and N4-DMTr-FTC (9) were synthesized as described in the previously published procedure. ${ }^{[12,13]}$ Peptidyl polyarginine dodecandicarboxylate resin $12(0.7 \mathrm{~g})$, the nucleoside analogues $(\mathbf{1}, \mathbf{8}$, or 9, $1.1 \mathrm{mmol}$ ), HBTU (417 mg, $1.1 \mathrm{mmol})$, and HOAt (148 mg, $1.1 \mathrm{mmol}$ ) were dissolved in anhydrous DMF $(25 \mathrm{~mL})$ in a round-bottomed flask $(100 \mathrm{~mL})$ followed by the addition of DIPEA $(1.95 \mathrm{mmol}, 342 \mu \mathrm{L})$ and DIC (2.5 mmol, $383 \mu \mathrm{L}$ ) (Scheme 2). The reaction vessels were flushed with $\mathrm{N}_{2}$ and placed on a shaker to mix the reagents. 
The reaction mixture was filtered off, and the resin was washed with DMF $(3 \times 20 \mathrm{~mL})$, methanol $(3 \times 20 \mathrm{~mL})$, and dichloromethane (DCM, $3 \times 20 \mathrm{~mL}$ ). The resin was cleaved together with the deprotection of $\mathrm{Pbf}$ and DMTr protective groups from the side chain of arginine and corresponding nucleosides, respectively, using reagent $\mathrm{R}(20 \mathrm{~mL})$ for 4 hours at room temperature. The resin was filtered, and the filtrate was added drop-wise to cold diethyl ether $(50 \mathrm{~mL})$ for precipitation followed by centrifugation at $4000 \mathrm{rpm}$. The precipitates were washed with diethyl ether $(2 \times 50 \mathrm{~mL})$ to afford solid crude peptide-nucleoside conjugates (13-15). The precipitates were dried and dissolved in $50 \%$ acetonitrile and water. The conjugates were purified by preparative reverse-phase HPLC (Shimadzu LC-8A preparative liquid chromatograph) on a Phenomenex-Gemini C18 column (10 $\mu \mathrm{m}$, $250 \times 21.2 \mathrm{~mm})$ at $10.0 \mathrm{~mL} /$ minute flow rate using a gradient of $10 \%$ acetonitrile $(0.1 \% \mathrm{TFA})$ in water $(0.1 \% \mathrm{TFA})$ to $100 \%$ acetonitrile $(0.1 \%$ TFA) (Table 2). Chromatograms were recorded at 220 and $265 \mathrm{~nm}$ using a UV detector. The purity of final products $(>95 \%)$ was confirmed by analytical HPLC. The chemical structures of compounds were determined by a SELDI-TOF mass spectrometer on a Ciphergen protein chip instrument using $\alpha$-cyano-4-hydroxycinnamic as a matrix and by ${ }^{1} \mathrm{H}$ and ${ }^{13} \mathrm{C}$ NMR.

1-[5'-O-(3'-Fluoro-2', 3'-dideoxythymidinyl)] tetradecan-1,14-dioate conjugate of PolyArg (FLT-OCO $\left(\mathrm{CH}_{2}\right)_{12} \mathrm{CONH}-\mathrm{RRRRRRR-OH,} \mathrm{13).} \mathrm{Yield}$ (210 mg, 60.5\%). ${ }^{1} \mathrm{H}$ NMR (400 MHz, $\left.\mathrm{CD}_{3} \mathrm{OD}, \delta \mathrm{ppm}\right): 7.30$ (s, $\left.1 \mathrm{H}, \mathrm{H}-6\right)$, $6.12\left(\mathrm{dd}, J=5.7\right.$ and $\left.8.6 \mathrm{~Hz}, 1 \mathrm{H}, \mathrm{H}-\mathrm{-}^{\prime}\right), 5.15(\mathrm{dd}, J=4.3$ and $53.2 \mathrm{~Hz}, 1 \mathrm{H}, \mathrm{H}-$ $\left.3^{\prime}\right)$, 4.04-4.26 (m, 7H, - NH-CH-CO), 3.90-4.00 (m, 1H, H-4'), 3.52-3.66 $\left(\mathrm{m}, 2 \mathrm{H}, \mathrm{H}-5^{\prime}\right.$ and $\left.\mathrm{H}-5^{\prime \prime}\right), 3.26-3.35\left(\mathrm{~m}, 2 \mathrm{H},=\mathrm{NH}-\mathrm{CH}_{2}\right), 2.95-3.10(\mathrm{~m}$, $\left.10 \mathrm{H},=\mathrm{NH}-\mathrm{CH}_{2}\right), 2.70-2.90\left(\mathrm{~m}, 2 \mathrm{H},=\mathrm{NH}-\mathrm{CH}_{2}\right), 2.40-2.55(\mathrm{~m}, 1 \mathrm{H}, \mathrm{H}-$ $\left.2^{\prime \prime}\right)$, 2.05-2.25 (m, 5H, $\mathrm{CH}_{2} \mathrm{O}$ and $\left.\mathrm{H}-2^{\prime}\right), 1.84-1.90$ (br s, $7 \mathrm{H}, 5-\mathrm{CH}_{3}$ and $\left.\mathrm{CH}_{2} \mathrm{CH}_{2} \mathrm{CO}\right), 1.35-1.80\left(\mathrm{~m}, 32 \mathrm{H},=\mathrm{NH}-\mathrm{CH}_{2}-\mathrm{CH}_{2}\right), 1.08-1.20(\mathrm{br} \mathrm{s}, 16 \mathrm{H}$, methylene protons). ${ }^{13} \mathrm{C}$ NMR $\left(\mathrm{CD}_{3} \mathrm{CN}, 100 \mathrm{MHz}, \delta \mathrm{ppm}\right): 175.87,173.26$, $172.79,172.69,156.36,135.79,118.26,114.78,84.89,82.22,63.19,52.82$, 51.83, 48.74, 40.22, 37.14, 33.16, 27.49, 24.07, 19.98, 19.25, 13.83, 11.43, 0.73, 0.52, 0.31, 0.11, 0.10, 0.36.MS (SELDI-TOF) (m/z): $\mathrm{C}_{66} \mathrm{H}_{121} \mathrm{FN}_{30} \mathrm{O}_{14}$, calcd, 1576.97; found, $1577.5[\mathrm{M}+\mathrm{H}]^{+}$.

1-[(-)-2',3'-Dideoxy-3'-thiacytidine]tetradecan-1,14-dioate conjugate of PolyArg (3TC-OCO $\left(\mathbf{C H}_{2}\right){ }_{12}$ CONH-RRRRRRR-OH, 14). Yield $(180 \mathrm{mg}$, $52.3 \%) .{ }^{1} \mathrm{H}$ NMR $\left(400 \mathrm{MHz}, \mathrm{CD}_{3} \mathrm{OD}, \delta \mathrm{ppm}\right): 8.27(\mathrm{~d}, J=7.8 \mathrm{~Hz}$, $1 \mathrm{H}, \mathrm{H}-6), 6.42-6.48\left(\mathrm{~m}, 1 \mathrm{H}, \mathrm{H}-1^{\prime}\right), 6.34(\mathrm{~d}, J=7.5 \mathrm{~Hz}, 1 \mathrm{H}, \mathrm{H}-5)$, $5.60-5.80\left(\mathrm{~m}, 1 \mathrm{H}, \mathrm{H}-4^{\prime}\right), 4.58-4.68(\mathrm{~m}, 1 \mathrm{H},-\mathrm{NH}-\mathrm{CH}-\mathrm{CO}), 4.40-4.50(\mathrm{br}$ $\mathrm{s}, 5 \mathrm{H},-\mathrm{NH}-\mathrm{C} H-\mathrm{CO}), 4.30-4.40(\mathrm{~m} 1 \mathrm{H},-\mathrm{NH}-\mathrm{C} H-\mathrm{CO}), 3.78(\mathrm{dd}, J=$ 12.8 and $\left.5.4 \mathrm{~Hz}, 1 \mathrm{H}, \mathrm{H}-5^{\prime \prime}\right), 3.61\left(\mathrm{~d}, J=12.8 \mathrm{~Hz}, 1 \mathrm{H}, \mathrm{H}-5^{\prime}\right), 3.42-3.52$ (m, 1H, H-2"), 3.22-3.40 (br s, 15H, H-2', = NH-CH $\left.H_{2}\right), 2.52-5.64(\mathrm{~m}, 2 \mathrm{H}$, $\left.\mathrm{CH}_{2} \mathrm{CONH}-\right)$, 2.36-2.44 (m, 2H, $\left.\mathrm{CH}_{2} \mathrm{COO}\right), 1.65-2.10(\mathrm{~m}, 32 \mathrm{H},=\mathrm{NH}-$ $\left.\mathrm{CH}_{2}-\mathrm{CH}_{2}\right), 1.30-1.50$ (br s, $16 \mathrm{H}$, methylene protons). ${ }^{13} \mathrm{C}$ NMR $\left(\mathrm{CD}_{3} \mathrm{CN}\right.$, 
TABLE 3 HPLC method used for stability and degradation studies

\begin{tabular}{lccc}
\hline Time (minute) & $\begin{array}{c}\text { Water Concentration } \\
\text { A (\%) }\end{array}$ & $\begin{array}{c}\text { Acetonitrile Concentration } \\
\text { B (\%) }\end{array}$ & $\begin{array}{c}\text { Flow Rate } \\
(\mathrm{mL} / \mathrm{minute})\end{array}$ \\
\hline 0.00 & 100.0 & 0.0 & 1.0 \\
1.00 & 100.0 & 0.0 & 1.0 \\
20.0 & 0.0 & 100.0 & 1.0 \\
25.0 & 0.0 & 100.0 & 1.0 \\
30.0 & 100.0 & 0.0 & 1.0 \\
35.0 & 100.0 & 0.0 & 1.0 \\
\hline
\end{tabular}

$100 \mathrm{MHz}, \delta \mathrm{ppm}): 176.50,176.46,174.91,173.47,172.76,172.69,172.65$, $172.59,172.48,162.08,161.74,159.40,156.29,148.20,143.62,94.00,86.78$, $84.18,63.21,53.17,52.83,52.77,52.43,40.17,36.95,35.03$, 33.33, 28.51, 28.38, 28.30, 28.11, 28.02, 27.91, 27.67, 27.57, 24.96, 24.21, 24.07, 24.01, 23.92. MS (SELDI-TOF) (m/z): $\mathrm{C}_{64} \mathrm{H}_{119} \mathrm{~N}_{31} \mathrm{O}_{13} \mathrm{~S}$, calcd, 1561.93; found, $1562.70[\mathrm{M}+\mathrm{H}]^{+}$.

1-[(-)-2', 3'-Dideoxy-5-fluoro-3'-thiacytidine $]$ tetradecan-1,14-dioate conjugate of PolyArg (FTC-OCO $\left(\mathrm{CH}_{2}\right)_{12} \mathrm{CONH}-\mathrm{RRRRRRR-OH,} \mathrm{15).} \mathrm{Yield}$ (130 mg, 37.5\%); ${ }^{1} \mathrm{H}$ NMR (400 MHz, $\left.\mathrm{CD}_{3} \mathrm{OD}, \delta \mathrm{ppm}\right): 8.11(\mathrm{~d}, J=6.7 \mathrm{~Hz}$, $1 \mathrm{H}, \mathrm{H}-6), 6.22-6.27\left(\mathrm{~m}, 1 \mathrm{H}, \mathrm{H}-1^{\prime}\right), 5.44(\mathrm{dd}, J=2.9$ and $4.3 \mathrm{~Hz}, 1 \mathrm{H}, \mathrm{H}-$ $\left.4^{\prime}\right), 4.68\left(\mathrm{dd}, J=12.6\right.$ and $\left.4.4 \mathrm{~Hz}, 1 \mathrm{H}, \mathrm{H}-5^{\prime \prime}\right), 4.30-4.48\left(\mathrm{~m}, 7 \mathrm{H}, \mathrm{H}-5^{\prime}\right.$, - $\mathrm{NH}-\mathrm{CH}-\mathrm{CO}), 4.20-4.30(\mathrm{~m}, 1 \mathrm{H},-\mathrm{NH}-\mathrm{CH}-\mathrm{CO}), 3.45-4.65(\mathrm{~m}, 1 \mathrm{H}$,

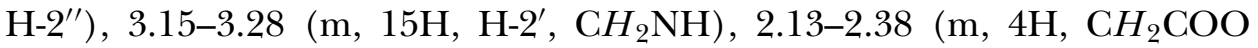
and $\left.\mathrm{CH}_{2} \mathrm{CONH}\right), 1.40-1.90(\mathrm{~m}, 32 \mathrm{H}$, methylene protons), 1.10-1.30 (br $\mathrm{s}, 16 \mathrm{H}$, methylene proton); ${ }^{13} \mathrm{C} \mathrm{NMR}\left(\mathrm{CD}_{3} \mathrm{CN}, 100 \mathrm{MHz}, \delta \mathrm{ppm}\right): 172.88$, $172.41,171.79,171.21,159.47,158.84,158.52,156.76,124.80,99.43,86.63$, 82.02, 63.77, 52.02, 40.04, 39.83, 39.62, 39.41, 39.20, 38.99, 38.78, 36.06, $35.05,33.16,28.87,28.79,28.35,28.26 .25 .15,24.86,24.29$. MS (MALDITOF) (m/z): $\mathrm{C}_{64} \mathrm{H}_{118} \mathrm{FN}_{31} \mathrm{O}_{13} \mathrm{~S}$, calcd, 1580.91; found, $1581.5[\mathrm{M}+\mathrm{H}]^{+}$.

Stability and Degradation Studies. The stability of 13 was evaluated by using HPLC. All degradation studies were carried out at a drug concentration of $1 \mathrm{mg} / \mathrm{mL}$. The solution stability studies were conducted by using the stock solution of compound 13 in the presence of room temperature $\left(25^{\circ} \mathrm{C}\right)$, heat $\left(40^{\circ} \mathrm{C}\right)$, neutral (water), acidic $(1 \mathrm{~N} \mathrm{HCl})$, alkaline $(1 \mathrm{~N} \mathrm{NaOH})$ and oxidation $\left(3 \% \mathrm{H}_{2} \mathrm{O}_{2}\right)$ conditions at $40^{\circ} \mathrm{C}$. The compound was incubated in the above mentioned solutions for 24 hours. All the samples were kept at room temperature for 1 hour, and analytical HPLC was run for 35 minutes. The solvent system used was water:acetonitrile $(0.1 \%$ trifluoroacetic acid $)$, and the HPLC was run at a flow rate of $1 \mathrm{~mL} /$ minute at $220 \mathrm{~nm}$ and $256 \mathrm{~nm}$ wavelengths (Table 3).

Partition Coefficient $(\log$ P). Log P HPLC studies were carried out by distributing $21.9 \mathrm{mg}$ of compound 13 in $250 \mu \mathrm{L}$ each of $n$-octanol (organic) and $\mathrm{pH} 4$ acetate buffer (aqueous). The mixture was stirred for 2 days at room temperature. The analytical HPLC was run using water:acetonitrile 
TABLE 4 Dissolution media composition for (6 liters)

\begin{tabular}{|c|c|c|c|c|c|c|c|c|c|}
\hline Chemicals & $\begin{array}{c}\text { Acetic } \\
\text { Acid }\end{array}$ & Urea & Glucose & $\begin{array}{c}\text { Lactic } \\
\text { Acid }\end{array}$ & Glycerol & $\begin{array}{l}\text { Potassium } \\
\text { Hydroxide }\end{array}$ & $\begin{array}{l}\text { Calcium } \\
\text { Hydroxide }\end{array}$ & $\begin{array}{l}\text { Sodium } \\
\text { Chloride }\end{array}$ & $\mathrm{pH}$ \\
\hline Weight (grams) & 6 & 24 & 30 & 12 & 0.96 & 8.4 & 1.3 & 21 & 4.2 \\
\hline
\end{tabular}

$(0.1 \%$ TFA) as a solvent system at a flow rate of $1 \mathrm{~mL} / \mathrm{minute}$ at 220 and $256 \mathrm{~nm}$ wavelengths for each collected fraction (Table 3).

Gel Formulations. Vaginal gel formulations of compound 13 were manufactured using non-ionic (HPC-SL) and anionic (Carbopol) polymers, with or without the inclusion of thermo-reversible gelling (Pluronic F-127) polymer. The HPC-SL formulation consisted of $2.25 \% \mathrm{w} / \mathrm{v}$ in water whereas Carbopol consisted of $0.2 \% \mathrm{w} / \mathrm{v}$. For thermogelling formulations, the aforementioned HPC-SL and Carbopol gels were mixed with a $20 \%$ solution of Pluronic F-127 (3:1 v/v ratio). A drug load comprising 1.6\% (w/v) of FLT conjugate was loaded in the gels and was sealed in SpectraPor dialysis tubing with MWCO of $3500 \mathrm{Da}$. The tubes were suspended in $70 \mathrm{~mL}$ of dissolution media (Table 4) held at $37 \pm 0.5^{\circ} \mathrm{C}$ with a stirring speed of $75 \mathrm{rpm}$ using a 0.5-inch stir bar. The dissolution media consisted of simulated vaginal fluid (Table 4). These dissolution samples were transferred to UV 96-well plates $\left(\right.$ Costar $\left.^{\circledR},\right)$ and were then analyzed using a SpectraMax M2 UV detector (Molecular Devices, PA, USA).

Anti-HIV Assays. The anti-HIV activity of the compounds was evaluated according to the previously reported procedure. ${ }^{11,19-21}$ Compound anti-HIV activity was evaluated in single-round (MAGI) infection assays using X4 (IIIB) and R5 (BaL) HIV-1 and P4R5 cells expressing CD4 and co-receptors. In summary, P4R5MAGI cells were cultured at a density of $1.2 \times 10^{4}$ cells/well in a 96-well plate approximately 18 hours prior to infection. Cells were incubated for 2 hours at $37^{\circ} \mathrm{C}$ with purified, cell-free HIV-1 laboratory strains IIIB or BaL (Advanced Biotechnologies, Inc., Columbia, MD), in the absence or presence of each agent. After 2 hours, cells were washed, cultured for an additional 46 hours, and subsequently assayed for HIV-1 infection using the Galacto-Star $\beta$-Galactosidase Reporter Gene Assay System for Mammalian Cells (Applied Biosystems, Bedford, MA). Reductions in infection were calculated as a percentage relative to the level of infection in the absence of agents, and $50 \%$ inhibitory concentrations $\left(\mathrm{EC}_{50}\right)$ were derived from regression analysis. Each compound concentration was tested in triplicate wells. Cell toxicity was evaluated using the same experimental design but without the addition of virus. The impact of compounds on cell viability was assessed using an MTT (reduction of tetrazolium salts) assay (Invitrogen, Carlsbad, CA). 


\section{FUNDING}

Support for this subproject (MSA-03-367) was provided by CONRAD, Eastern Virginia Medical School under a Cooperative Agreement (HRNA-00-98-00020-00) with the United States Agency for International Development (USAID). We also acknowledge National Center for Research Resources, NIH, and Grant Number 8 P20 GM103430-12 for sponsoring the core facility.

\section{REFERENCES}

1. Clercq, E.D. The Design of Drugs for HIV and HCV. Nature Rev. Drug Disc., 2007, 6, 1001-1018.

2. Langner, C.A.; Travis, J.K.; Caldwell, S.J.; Tianbao, J.E.; Li, Q.; Bryant, M.L.; Devadas, B.; Gokel, G.W.; Kobayashi, G.S.; Gordon, J. I. 4-oxatetradecanoic acid is fungicidal for cryptococcus neoformans and inhibits replication of human immunodeficiency virus I. J. Biol. Chem. 1992, 267, 17159-17169.

3. Farazi, T.A.; Waksman, G.; Gordon, J.I. The biology and enzymology of protein N-myristoulation. J. Biol. Chem. 2001, 276, 39501-39504.

4. Bryant, M.L.; McWherter, C.A.; Kishore, N.S.; Gokel, G.W.; Gordon, J.I.; Myristoyl Co A: protein $\mathrm{N}$-myristoyltransferase as a therapeutic target for inhibiting replication of human immunodeficiency virus-1. Perspect. Drug Dis. Des. 1993, 1, 193-209.

5. Takamune, N.; Hamada, H.; Misumi, S.; Shoji, S. Novel strategy for anti-HIV-1 action: selective cytotoxic effect of N-myristoyltransferase inhibitor on HIV-1-infecteted cells. FEBS letters 2002, 527, 138-142.

6. Parang, K.; Wiebe, L.I.; Knaus, E.E.; Huang, J.S.; Tyrrell, D.L.; Csizmadia, F. In vitro antiviral activities of myristic acid analogs against human immunodeficiency and hepatitis B viruses. Antiviral Res. 1997, 34, 75-90.

7. Parang, K.; Knaus, E.E.; Wiebe, L.I.; Sardari, S.; Daneshtalab, M.; Csizmadia, F. Synthesis and antifungal activities of myristic acid analogs. Arch. Pharm.-Pharm. Med. Chem. 1996, 329, 475-482.

8. Parang, K., Knaus, E.E., Wiebe, L.I. Synthesis, in vitro anti-HIV structure-activity relationships and stability of 5'-O-myristoyl analogue derivatives of $3^{\prime}$-azido-2', $3^{\prime}$-dideoxythymidine as potential prodrugs of 3'-azido-2', 3'-dideoxythymidine (AZT). Antiviral. Chem. Chemother. 1998, 9, 311-323.

9. Parang, K., Knaus, E.E., Wiebe, L.I. Synthesis, in vitro anti-HIV activity, and biological stability of $5^{\prime}$-O-myristoyl analogue derivatives of $3^{\prime}$-fluoro-2', $3^{\prime}$-dideoxythymidine (FLT) as potential prodrugs of FLT. Nucleosides E Nucleotides 1998, 17, 987-1008.

10. Parang, K., Wiebe, L.I., Knaus, E.E. Novel approaches for designing $5^{\prime}$-O-ester prodrugs of $3^{\prime}$-azido2',3'-dideoxythymidine (AZT). Curr. Med. Chem. 2000, 7, 995-1039.

11. Agarwal, H.K.; Loethan, K.; Mandal, D.; Doncel, G.F.; Parang, K. Synthesis and biological evaluation of fatty acyl ester derivatives of $2^{\prime}, 3^{\prime}$-didehydro-2', $3^{\prime}$-dideoxythymidine. Bioorg. Med. Chem. Lett. 2011, 21, 1917-1921.

12. Agarwal, H.K.; Chhikara, B.S.; Hanley, M.J.; Ye, G.; Doncel, G.F.; Parang, K. Synthesis and biological evaluation of fatty acyl ester derivatives of (-)-2', $3^{\prime}$-dideoxy-3'-thiacytidine. J. Med. Chem. 2012, 55, 4861-4871.

13. Agarwal, H.K.; Chhikara, B.S.; Bhavaraju, S.; Mandal, D.; Doncel, G.F.; Parang, K. Emtricitabine prodrugs with improved anti-HIV activity and cellular uptake. Mol. Pharmaceutics 2013, 10, 467-476.

14. Pemmaraju, B.; Agarwal, H.K.; Oh, D.; Buckheit, K.W.; Buckheit Jr. R.W.; Tiwari, R.; Parang, K. Synthesis and biological evaluation of $5^{\prime}$-O-dicarboxylic fatty acyl monoester derivatives of anti-HIV nucleoside reverse transcriptase inhibitors. Tetrahedron Lett. 2014, 55, 1983-1986.

15. Gangadhara, K.L.; Lescrinier, E.; Pannecouque, C.; Herdewijn, P. Hydroxy fatty acids for the delivery of dideoxynucleosides as anti-HIV agents. Bioorg. Med. Chem. Lett. 2014, 24, 817-820.

16. Krečmerová, M.; Pohl, R.; Masojídková, M.; Balzarini, J.; Snoeck, R.; Andrei, G. N(4)-Acyl derivatives as lipophilic prodrugs of cidofovir and its 5-azacytosine analogue, (S)-HPMP-5-azaC: chemistry and antiviral activity. Bioorg Med Chem. 2014, 22, 2896-906. 
17. Wender, P.A.; Galliher, W.C.; Goun, E.A.; Jones, L.R.; Pillow, T.H. The design of guanidiniumrich transporters and their internalization mechanisms. Adv. Drug Deliv. Rev. 2008, 60(4-5), $452-472$.

18. Rothbard, J.B.; Garlington, S.; Lin, Q.; Kirschberg, T.; Kreider, E.; McGrane, P.L.; Wender, P.A.; Khavari, P.A. Conjugation of arginine oligomers to cyclosporin A facilitates topical delivery and inhibition of inflammation. Nat. Med. 2000, 6, 1253-1257.

19. Agarwal, H.K.; Kumar, A.; Doncel, G.F.; Parang, K. Synthesis, antiviral and contraceptive activities of nucleoside-sodium cellulose sulfate acetate and succinate conjugates. Bioorg. Med. Chem. Lett. 2010, 20, 6993-6997.

20. Ahmadibeni, Y.; Tiwari, R.; Swepson, C.; Pandhare, J.; Dash, C.; Doncel, G.F.; Parang, K. Synthesis and anti-HIV activities of bis-(cycloSaligenyl) pronucleotides derivatives of $3^{\prime}$-fluoro-3'-deoxythymidine and 3'-azido-3'-deoxythymidine. Tetrahedron Lett. 2011, 52, 802-805.

21. Krebs, F.C.; Miller, S.R.; Ferguson, M.L.; Labib, M.; Rando, R.F.; Wigdahl, B. Polybiguanides, particularly biguanide, have activity against human immunodeficiency virus type. Biomed. Pharmacother. 2005, 59, 438-445.

22. Meylan, P.R.A.; Kornbluth, R.S.; Zbinden, I.; Dichman, D.D. Influence of host cell type and V3 loop of the surface glycoprotein on susceptibility of human immunodeficiency virus type 1 to polyanion compounds. Antimicrob. Agents Chemother. 1994, 38, 2910-2916.

23. Moulard, M.; Lortat-Jacob, H.; Mondor, I.; Roca, G.; Wyatt, R.; Sodroski, J.; Zhao, L.; Olson, W.; Kwong, P.D.; Attentau, Q.J. Selective interactions of polyanions with basic surfaces on human immunodeficiency virus type 1 gp120. J. Virol. 2000, 74, 1948-1960. 